\title{
Implementasi dan Pengukuran Pengalaman Pengguna Sistem Informasi Rehabilitasi Korban Penyalahgunaan NAPZA Menggunakan HEART Framework
}

\author{
Okta Verina Tri Utami*, Citra Wiguna, Dwi Mustika Kusumawardani \\ S1 Sistem Informasi, Fakultas Informatika, Institut Teknologi Telkom Purwokerto \\ Jalan D.I Panjaitan 128 Purwokerto, Banyumas, Jawa Tengah \\ *e-mail: 17103016@ittelkom-pwt.ac.id
}

(received: 23 Februari 2021, revised: 12 April 2021, accepted: 19 April 2021)

\begin{abstract}
Abstrak
Sistem informasi rehabilitasi korban penyalahgunaan NAPZA merupakan sebuah sistem yang dibangun oleh developer systems untuk mengelola dan mendistribusikan informasi guna mempermudah pengambilan keputusan oleh pihak manajemen Kantor BRSKPN Satria. Dalam penerapan tahap awal sistem informasi rehabilitasi, pihak manajemen melakukan pengukuran guna mendapatkan feedback terhadap pengalaman pengguna sistem. Sistem ini telah digunakan selama satu bulan sebagai tahap awal penerapan. Penelitian ini menggunakan metode HEART framework untuk mengukur pengalaman pengguna dengan lima variabel, yaitu Happiness, Engagement, Adoption, Retention, dan Task Success. Hasil penelitian ini menunjukkan variabel Happiness 50\% Sangat Setuju, variabel Engagement 43\% Sangat Setuju, variabel Adoption 45\% Sangat Setuju, variabel Retention 34\% Sangat Setuju, dan Task Success 38\% Sangat Setuju. Hasil menunjukkan tiga dari lima variabel HEART framework bernilai sangat setuju, yang memiliki arti sistem informasi rehabilitasi yang telah dievaluasi dapat diterima berdasarkan pengalaman pengguna. Sistem informasi rehabilitasi telah dilakukan pengukuran dan menunjukkan level usability pada kriteria "very high" dengan menggunakan Correlation Coefficient berdasarkan lima variabel HEART framework.
\end{abstract}

Kata kunci: Sistem informasi, rehabilitasi, pengalaman pengguna, user experience, HEART framework

\begin{abstract}
The rehabilitation information system for drug abuse victims is a system developed by developer systems to manage and distribute information to facilitate decision making by the management of the Satria BRSKPN Office. In implementing the early stages of the rehabilitation information system, the management takes measurements in order to get feedback on the experience of the system users. This system has been in use for one month as an initial stage of implementation. This study uses the HEART framework method to measure user experience with five variables, namely Happiness, Engagement, Adoption, Retention, and Task Success. The results of this study indicate the variable Happiness 50\% Strongly Agree, 43\% Strongly Agree Engagement variable, 45\% Strongly Agree Adoption variable, 34\% Strongly Agree Retention variable, and 38\% Strongly Agree Task Success variable. The results show that three of the five HEART framework variables are highly agree, which means that the rehabilitation information system that has been evaluated is acceptable based on user experience. The rehabilitation information system has been measured and shows the level of usability on the "very high" criteria using the Correlation Coefficient based on the five HEART framework variables.
\end{abstract}

Keywords: Information systems, rehabilitation, user experience, user experience, HEART framework 


\section{Pendahuluan}

Narkotika, Psikotropika dan Bahan Adiktif berbahan Aktif (narkoba) merupakan zat atau obat tertentu untuk mereka yang menggunakannya dengan cara memasukan obat tersebut ke dalam tubuhnya, sehingga menimbulkan efek halusinasi, pembiasan, hilangnya rasa sakit, dan dapat menimbulkan kecanduan[1]. Indonesia merupakan salah satu negara dengan tingkat penggunaan narkoba cukup tinggi dengan sejumlah 33.371 kasus narkotika. Penggunaan narkoba di Indonesia tersebar merata di seluruh provinsi. Hasil survei Badan Narkotika Nasional Indonesia tahun 2019 menyatakan terdapat 654 kawasan rawan narkoba yang terbagi di 34 provinsi[2]. Kementrian Sosial Republik Indonesia menjadi salah satu lembaga yang bertanggung jawab untuk melaksanakan program rehabilitasi sosial bagi korban penyalahgunaan NAPZA. Kantor Balai Rehabilitasi Korban Penyalahgunaan NAPZA (BRSKPN) Satria merupakan salah satu Unit Pelaksana Teknis Kementrian Sosial Republik Indonesia yang bertugas untuk melaksanakan rehabilitasi sosial korban penyalahgunaan NAPZA[3].

Seiring berkembangnya teknologi informasi dan komunikasi menjadikan seluruh instansi pemerintahan ikut serta menerapkan teknologi. Proses rehabilitasi yang dijalankan oleh Kantor BRSKPN Satria saat ini masih dicatat pada sebuah form manual pada beberapa lembaran kertas, dan kemudian didokumentasikan dengan cara manual menggunakan Microsoft Office. Data-data rehabilitasi korban penyalahgunaan NAPZA tentunya harus dikelola dengan baik untuk pelaksanaan proses rehabilitasi hingga pemantauan perkembangan korban. Sehingga Kantor BRSKPN harus menerapkan sistem informasi untuk mengelola proses rehabilitasi.

Sistem informasi rehabilitasi korban penyalahgunaan NAPZA telah dirancang berbasis website menggunakan metode waterfall. Keuntungan menggunakan metode waterfall antara lain yaitu sederhana, mudah dipahami dan diterapkan. Metode waterfall bekerja dengan baik dan memberikan hasil yang benar. Tahap yang dijalankan ketat dan tepat, setiap tahapan dieksekusi satu per satu, sehingga mudah dikelola. Kriteria awal dan akhir didefinisikan dengan baik. Hal tersebut menjamin kualitas dan tercapainya tujuan. Metode ini berfokus pada dokumentasi yang baik[4]. Sehingga metode waterfall cocok diterapkan untuk membuat sistem informasi rehabilitasi korban penyalahgunaan NAPZA di Kantor BRSKPN Satria Baturaden.

Sistem informasi rehabilitasi korban penyalahgunaan NAPZA yang sudah dirancang dan diimplementasikan pada pegawai Kantor BRSKPN Satria harus dilakukan pengujian dari segi pengalaman pengguna (user experience), untuk memastikan bahwa sistem informasi tersebut dapat berfungsi dengan baik. Pengalaman pengguna sering dikaitkan dengan relasi interaksi manusia terhadap sistem aplikasi terkomputerisasi. Pengalaman pengguna juga diasosiasikan sebagai persepsi dan tanggapan pengguna terhadap hasil interaksinya dengan sebuah sistem[5].

Elemen user experience (UX) dalam pengembangan sebuah sistem informasi mempunyai peranan penting dengan melibatkan pengalaman pengguna dalam mencapai tujuan yang diinginkan[6]. Adanya pengukuran evaluasi dengan pendekatan UX berfungsi untuk mengetahui apa yang dirasakan oleh pengguna, apakah pengguna merasa senang, mendapatkan kemudahan, memiliki perasaan tertekan atau merasa puas ketika menggunakan sistem informasi rehabilitasi korban penyalahgunaan NAPZA[7]. Penelitian ini bertujuan untuk melakukan pengukuran menggunakan pendekatan UX yang dilakukan kepada pegawai Kantor BRSKPN Satria dalam menggunakan sistem informasi rehabilitasi korban penyalahgunaan NAPZA.

Pengukuran UX yang dilakukan pada penelitian ini menggunakan HEART framework. HEART framework merupakan pengukuran UX berdasarkan user-centered metrics. Framework tersebut merupakan hasil pengembangan Google dan telah digeneralisasi ke beberapa perusahaan Google sehingga diyakini bahwa organisasi lain dapat memakai kembali atau mengadaptasi HEART framework[8].

\section{Tinjauan Literatur}

Sebuah sistem informasi telah banyak diterapkan di sebuah instansi atau organisasi pemerintahan untuk mendukung proses bisnis. Sistem informasi merupakan kerangka kerja yang mengkoordinasikan sumber daya (komputer dan manusia) untuk mengubah masukan (input) menjadi keluaran sebuah informasi, guna mencapai sasaran-sasaran organisasi atau perusahaan[9]. Salah satu instansi pemerintah yang menerapkan sistem informasi rehabilitasi narkoba yaitu BNNK 
Pematangsiantar, yang berfungsi untuk mempermudah pegawai dalam mengelola dan mengakses kembali data yang sudah tersimpan di database. Data yang tersimpan pada sistem informasi rehabilitasi BNNK Pematangsiantar yaitu data registrasi, data pasien, keluarga, konselor, dan data rehabilitasi[10].

Sebuah sistem informasi yang sudah diimplementasikan harus dinilai dari aspek user experience. User experience atau pengalaman pengguna menggambarkan ukuran subjektif dari segi pengguna terhadap sebuah perangkat lunak yang digunakan. Sekelompok pengguna yang berbeda tentunya menghasilkan perbedaan ukuran terhadap pengalaman pengguna. Pengukuran pengalaman pengguna memerlukan sebuah alat untuk mengumpulkan respon subjektif terhadap perangkat lunak yang digunakan. Salah satu cara yang efektif untuk melakukan pengukuran pengalaman pengguna yaitu penggunaan kuesioner[11].

Terdapat beberapa metode yang digunakan untuk mengukur UX pada sebuah sistem informasi, salah satunya yaitu metode User Experience Questionnaire (UEQ). Pada UEQ terdapat 6 komponen (attractiveness, perspicuity, dependability, efficiency, novelty, stimulation) dengan 26 pertanyaan. Salah satu contoh penggunaan $U E Q$ yaitu pengukuran UX pada e-learning di lingkungan universitas. User experience merupakan istilah pengalaman pengguna dalam merasakan suatu kemudahan dan efisiensi dalam interaksi manusia dengan komputer. Keberhasilan sebuah sistem informasi dapat diperoleh dengan analisis kebutuhan pengguna yang berfokus pada pengalaman dan kenyamanan pengguna. Pengukuran UX pada e-learning pada sebuah universitas XYZ memperoleh hasil pengukuran pada level below average. Hasil pengukuran dapat berfungsi sebagai rekomendasi perancangan design e-learning yang baru[12].

Metode HEART merupakan metode pengukuran UX yang dikembangkan oleh Google. Metode ini HEART pernah digunakan untuk mengukur UX pada sistem informasi akademik. Metode HEART yaitu akronim dari 5 komponen metode yang terdiri dari happiness, engagement, attitude, retention, dan task success. Happiness mencakup kepuasan pengguna pada saat menggunakan sistem informasi, Task Success mencakup efektifitas dan efisiensi dari sistem informasi tersebut dalam menyelesaikan tugas pengguna, Engagement, Adoption, dan Retention merupakan kategori baru yang digunakan untuk mengukur perilaku pada skala besar[13]. Sehingga metodeHEART dapat digunakan untuk mengukur emosi pengguna pada sebuah produk. Berdasarkan penggunaan metode HEART dalam mengukur UX pada sistem informasi akademik memperoleh kesimpulan bahwa perasaan senang dan efisiensi, dalam penyelesaian tugas pada saat menggunakan sistem informasi akademik dapat berpengaruh terhadap keinginan pengguna untuk menggunakan sistem informasi tersebut[7].

Analisis UX juga dapat diterapkan pada pengukuran penggunaan aplikasi mobile. Salah satunya yaitu pengukuran UX pada aplikasi Academic Information System (AIS) berbasis mobile. Pengukuran pada AIS berfokus pada user-centered metrics. Hasil pengukuran tersebut menyarankan untuk dilakukan re-design AIS mobile secara UX maupun UI[8].

\section{Metode Penelitian}

Dalam penelitian ini terdapat lima tahapan yang dilakukan. Tahap pertama, dilakukan implementasi sistem informasi rehabilitasi korban penyalahgunaan NAPZA kepada pegawai Kantor BRSKPN Satria dalam waktu satu bulan. Tahap ke dua yaitu penyusunan instrumen pengukuran tingkat pengalaman pengguna menggunakan HEART framework. Instrumen yang disusun berupa pertanyaan kuesioner yang terdiri dari 20 pertanyaan, dengan skala likert 1-5, yakni Sangat Tidak Setuju (STS), Tidak Setuju (TS), Netral (N), Setuju (S), dan Sangat Setuju (SS). Instrumen pertanyaan berdasarkan HEART framework ditunjukkan pada Tabel 1.

Tabel 1. Pertanyaan HEART framework

\begin{tabular}{|c|l|}
\hline Kode & \multicolumn{1}{|c|}{ Pertanyaan } \\
\hline H1 & Saya merasa puas setelah menggunakan sistem informasi rehabilitasi \\
\hline H2 & Saya merasa sistem informasi rehabilitasi mudah digunakan \\
\hline H3 & Saya menyukai ide tampilan/user interface dari sistem informasi rehabilitasi \\
\hline H4 & Saya merasa nyaman ketika menggunakan sistem informasi rehabilitasi \\
\hline H5 & Saya merasa harus memakai sistem informasi rehabilitasi \\
\hline E1 & Saya dapat menggunakan sistem informasi rehabilitasi ketika saya membutuhkan \\
\hline
\end{tabular}




\begin{tabular}{|l|l|}
\hline & informasi terkait data rehabilitasi \\
\hline E2 & $\begin{array}{l}\text { Saya perlu menggunakan sistem informasi rehabilitasi pada saat mengisi data } \\
\text { residen }\end{array}$ \\
\hline E3 & Sistem informasi rehabilitasi dapat diakses setiap waktu \\
\hline E4 & Saya rutin melakukan pengisian data pada sistem informasi rehabilitasi \\
\hline A1 & Saya tahu bagaimana menggunakan sistem informasi rehabilitasi \\
\hline A2 & Saya merasa sistem informasi rehabilitasi dapat memenuhi kebutuhan saya \\
\hline R1 & Saya akan sering menggunakan fitur-fitur sistem informasi rehabilitasi \\
\hline R2 & $\begin{array}{l}\text { Saya akan terus menggunakan sistem informasi rehabilitasi selama menjadi } \\
\text { pegawai Kantor BRSKPN Satria }\end{array}$ \\
\hline R3 & $\begin{array}{l}\text { Kualitas sistem informasi rehabilitasi sudah baik } \\
\text { R4 } \\
\text { informasi residen }\end{array}$ \\
\hline R5 & $\begin{array}{l}\text { Saya menggunakan sistem informasi rehabilitasi disaat akan melengkapi data } \\
\text { residen saja }\end{array}$ \\
\hline T1 & $\begin{array}{l}\text { Saya dapat menyelesaikan banyak hal terkait pelayanan rehabilitasi terhadap } \\
\text { residen }\end{array}$ \\
\hline T2 & Saya dapat melakukan dengan mudah di saat mengisi data seputar residen \\
\hline T3 & Saya dapat mempersingkat waktu dalam mengurus data residen \\
\hline T4 & $\begin{array}{l}\text { Dengan menggunakan sistem informasi rehabilitasi saya dapat melihat data-data } \\
\text { residen dengan lebih cepat }\end{array}$ \\
\hline
\end{tabular}

Tahap ke tiga yaitu penyebaran kuesioner penelitian kepada 10 responden pegawai rehabilitasi Kantor BRSKPN Satria yang terdiri dari psikolog, pekerja sosial, pegawai asesmen, dan perawat. Tahap ke empat yaitu pengolahan hasil kuesioner dengan menggunakan Microsoft Excel. Tahap ke lima yaitu analisis hasil pengolahan data tingkat keberhasilan implementasi sistem informasi rehabilitasi pada Kantor BRSKPN Satria.

\section{Hasil dan Pembahasan}

\subsection{Analisa Menggunakan Metode HEART framework}

Setelah melakukan penyebaran kuesioner kepada responden, selanjutnya dilakukan penghitungan hasil kuesioner sesuai dengan metode HEART framework. Perhitungan nilai masingmasing variabel terdiri dari tahapan sebagai berikut :

a. Tahap pertama yaitu mencari nilai max untuk setiap kriteria. Nilai max menunjukkan nilai yang diharapkan developer untuk kepuasan suatu sistem. Nilai max didapat dari jumlah sampel dikali nilai ekspektasi dikali jumlah pertanyaan.

b. Tahap ke dua yaitu menghitung total nilai setiap kriteria. Total nilai menunjukkan nilai yang diperoleh setelah penyebaran kuesioner pada responden. Total nilai diperoleh dari jumlah keseluruhan nilai setiap pertanyaan.

c. Tahap ke tiga yaitu menilai setiap kriteria. Penliaian kriteria menunjukkan nilai yang dihasilkan setelah mengetahui nilai max dan total nilai responden. Penilaian kriteria diperoleh dari total nilai dibagi nilai max dikalikan $100 \%$.

d. Tahap ke empat yaitu menghitung rata-rata semua variabel.

e. Langkah terakhir yaitu menghitung tingkat kegunaan. Tingkat kegunaan menunjukkan nilai yang dihasilkan setelah memperoleh seluruh kuesioner, nilai max, dan total nilai[14].

Hasil dengan menggunakan metode HEART framework ditunjukkan pada Tabel 2.

Tabel 2. Pengujian HEART framework

\begin{tabular}{|c|c|c|c|c|c|}
\hline Variabel & $\begin{array}{c}\text { Jumlah } \\
\text { Pertanyaan }\end{array}$ & Nilai Max & Total Nilai & $\begin{array}{c}\text { Nilai } \\
\text { Kriteria }\end{array}$ & Kategori \\
\hline Happiness & 5 & 250 & 216 & 0.864 & Very high \\
\hline Engagement & 5 & 200 & 171 & 0.855 & Very high \\
\hline Adoption & 2 & 100 & 86 & 0.86 & Very high \\
\hline Retention & 5 & 250 & 205 & 0.82 & Very high \\
\hline Task Success & 4 & 200 & 170 & 0.85 & Very high \\
\hline
\end{tabular}


Hasil skor pengujian HEART framework akan mendapatkan level of usability berdasarkan total hasil perhitungan. Tabel level of usability ditunjukkan pada Tabel 3.

Tabel 3. Level of usability [15]

\begin{tabular}{|c|c|}
\hline Correlation Coefficient & Reliability Criteria \\
\hline $0,81<\mathrm{r}<1,00$ & Very High \\
\hline $0,61<\mathrm{r}<0,80$ & High \\
\hline $0,41<\mathrm{r}<0,60$ & Natural \\
\hline $0,21<\mathrm{r}<0,40$ & Low \\
\hline $0,00<\mathrm{r}<0,01$ & Very Low \\
\hline
\end{tabular}

Berdasarkan hasil pengujian efektivitas sistem informasi menggunakan HEART framework pada Tabel 2 dapat dilihat pada aspek Happiness (perasaan senang atau bahagia pengguna) jumlah nilai kriteria sebesar 0.864, aspek Engagement (ketertarikan pengguna) jumlah nilai kriteria sebesar 0.8555 , aspek Adoption (penerimaan sebuah sistem) jumlah nilai kriteria sebesar 0.86, aspek Retention (keaktifan pengguna) jumlah nilai kriteria sebesar 0.82, dan aspek Task Success (keberhasilan pengguna) jumlah nilai kriteria sebesar 0.85 . Hasil keseluruhan nilai kriteria jika dikategorikan menggunakan level of usability seperti pada Tabel 3, hasil nilai kriterianya berada di atas 0.81 dan berarti keseluruhan hasil pengujian HEART termasuk pada kategori very high.

\subsection{Implementasi Sistem Informasi Rehabilitasi}

Sistem informasi rehabilitasi korban penyalahgunaan NAPZA sudah berhasil dirancang berbasis website dan diimplementasikan kepada pegawai rehabilitasi Kantor BRSKPN Satria, yang terdiri dari pegawai asesmen, pekerja sosial, psikolog, dan pekerja sosial. Hasil implementasi sistem informasi ditunjukan sebagai berikut.

\subsubsection{Login}

Tampilan halaman login dapat diakses oleh semua user yaitu admin, pegawai asesmen, pekerja sosial, perawat, dan psikolog. Halaman login ditunjukkan pada Gambar 1. Halaman login berfungsi untuk memasukkan username dan password agar pengguna memiliki hak akses sistem informasi rehabilitasi korban penyalahgunaan NAPZA.



Gambar 1. Tampilan Halaman Login

\subsubsection{Dashboard user}

Tampilan dashboard user berisi side bar menu dan tulisan selamat datang. Salah satu dashboard user perawat ditunjukkan pada Gambar 2. Halaman ini berfungsi untuk menampilkan menu utama yang terdiri menu form dan tables untuk melihat data pegawai asesmen. 

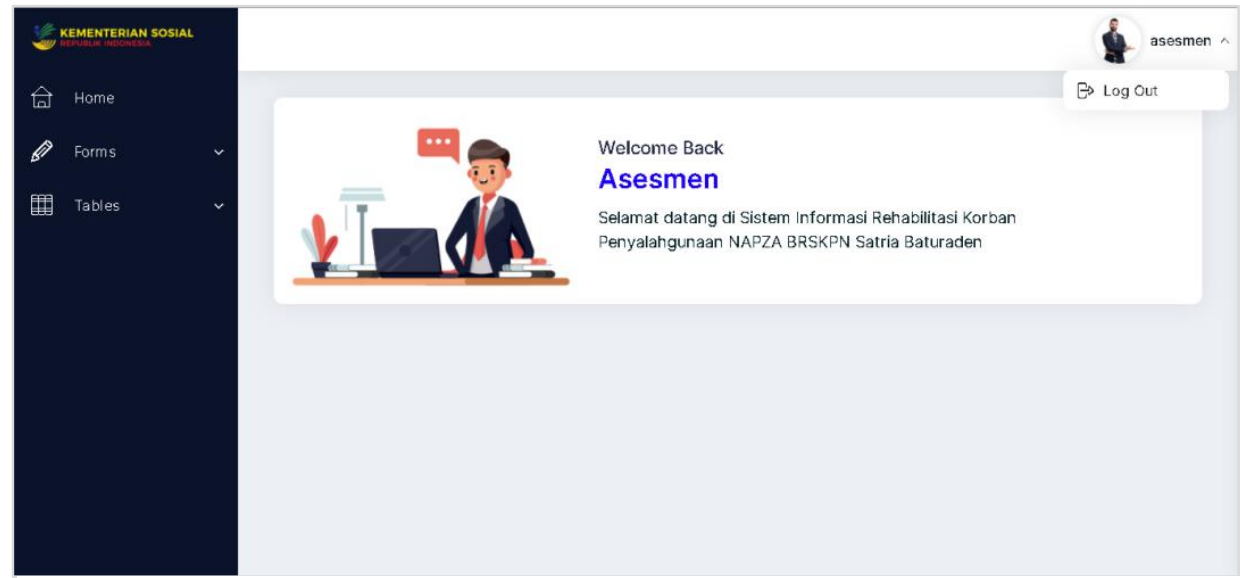

Gambar 2. Dashboard user

\subsubsection{Tampilan form}

Halaman form setiap user berbeda-beda disesuaikan dengan hak akses masing-masing user. Salah satu bentuk tampilan form user pekerja sosial ditunjukkan pada Gambar 3. Halaman ini berfungsi untuk menginputkan data WHOQOL ke dalam sistem informasi rehabilitasi korban penyalahgunaan NAPZA.
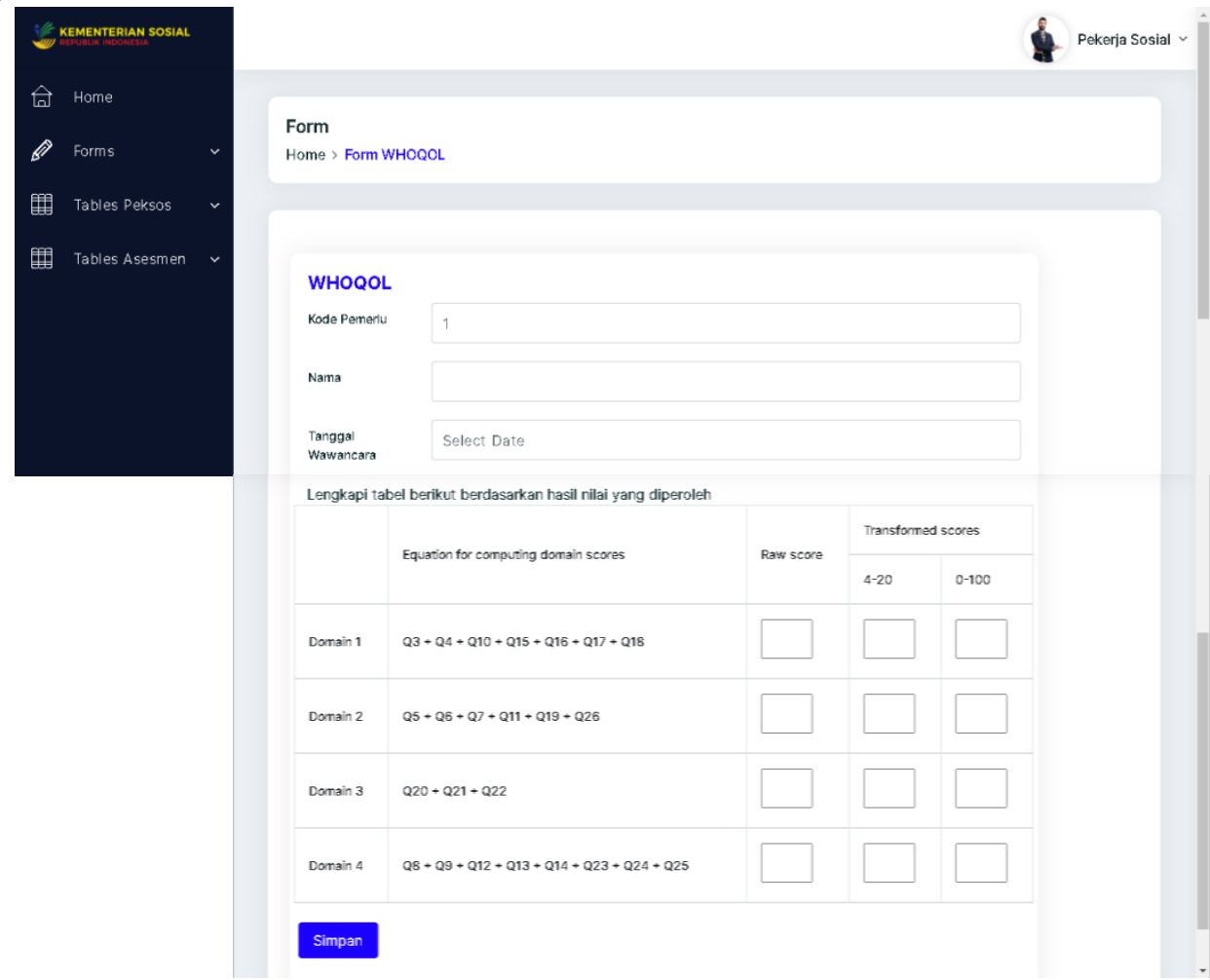

\section{Gambar 3. Form Pekerja Sosial}

\subsection{Pengujian Cronbach Alpha}

Pada tahap ini uji reliabilitas yang dilakukan menggunakan menggunakan metode Cronbach Alpha.Rumus Cronbach Alpha:

$$
\mathrm{r}=[\mathrm{k} /(\mathrm{k}-1)] *\left[1-\sum \sigma \mathrm{b} 2 / \sigma \mathrm{t} 2\right]
$$


Keterangan

$\mathrm{r}=$ koefisien reusabilitas instrument Cronbach Alpha

$\mathrm{k}=$ jumlah poin pertanyaan

$\Sigma \sigma b 2=$ total varian butir pertanyaan

$\sigma \mathrm{t} 2=$ varian total

$$
\begin{aligned}
& r=\left[\frac{5}{(5-1)}\right] *\left[1-\left[\frac{9,940}{139,560}\right]\right. \\
& r=0,978
\end{aligned}
$$

Hasil pengujian menunjukkan tingkat reliabilitas yang tinggi karena nilai koefisien kriteria $\geq 0,60$ sehingga dapat dikatakan setiap variabel HEART dalam penelitian ini reliabel. Hasil uji reliabilitas jika dibandingkan dengan $r$-tabel ditunjukkan pada Tabel 4.

Tabel 4. Uji Reliabilitas

\begin{tabular}{|c|c|}
\hline Cronbach Alpha Test & R-tabel \\
\hline 0.978 & 0,632 \\
\hline
\end{tabular}

Berdasarkan uji reliabilitas pada Tabel 2 memperoleh hasil nilai Cronbach's Alphasebesar 0.978 dan lebih besar dari $r$-tabel 0,632. Sehingga nilai tersebut menunjukkan ke-20 pertanyaan terbukti reliabel.

\subsection{Implementasi HEART framework}

Hasil analisis HEART framework respon dari 10 responden dikelompokan menjadi 5 aspek, yaitu Happines, Engagement, Adoption, Retention, dan Task Success.

\subsubsection{Happiness}

Cara menghitung hasil kuesioner variabel Happiness dilakukan dengan melihat skala likert yang dipilih kemudian dibagi dengan jumlah data pada variabel Happiness dikalikan 100. Lakukan langkah perhitungan yang sama untuk setiap varibel. Analisis respon responden terhadap aspek Happiness sangat setuju sebagai berikut.

$$
\text { Sangat Setuju }=\frac{24}{50} * 100=48
$$

Hasil analisis respon responden pada varibael Happiness menunjukan presentase $48 \%$ untuk jawaban sangat setuju, 36\% untuk jawaban setuju, dan $16 \%$ untuk jawaban netral. Hasil analisis aspek Happiness ditunjukkan pada Gambar 4.

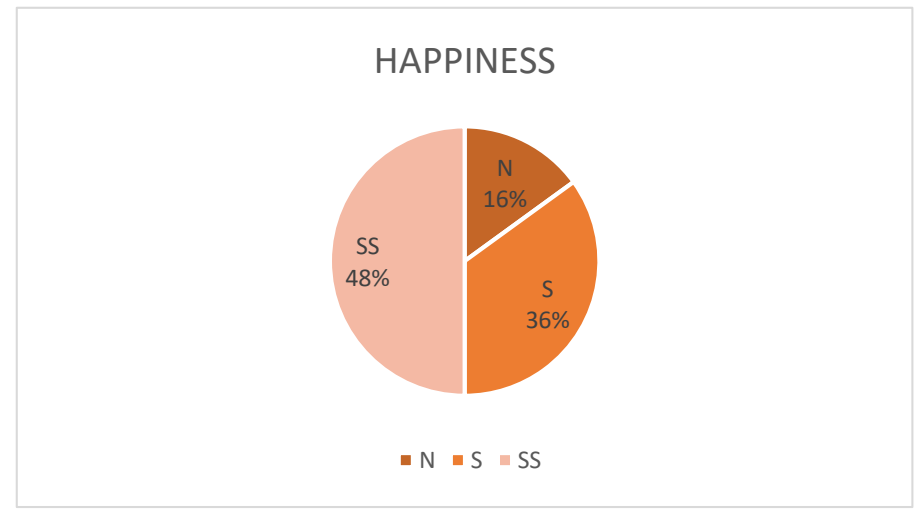

Gambar 4. Pie Chart Aspek Happiness

\subsubsection{Engagement}

Hasil analisis respon responden terhadap aspek Engagement menunjukan presentase 43\% untuk jawaban sangat setuju, $42 \%$ untuk jawaban setuju, dan $15 \%$ untuk jawaban netral. Hasil analisis aspek Engagement ditunjukkan pada Gambar 5. 




\section{Gambar 5. Pie Chart Aspek Engagement}

\subsubsection{Adoption}

Hasil analisis respon responden terhadap aspek Adoption menunjukan presentase $45 \%$ untuk jawaban sangat setuju, $40 \%$ untuk jawaban setuju, dan $15 \%$ untuk jawaban netral. Hasil analisis aspek Adoption ditunjukkan pada Gambar 6.

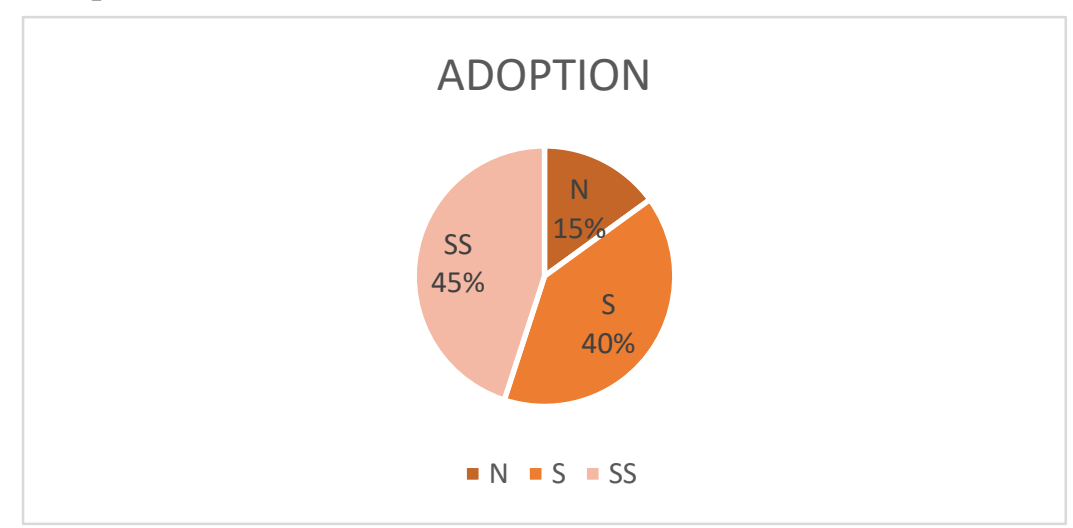

Gambar 6. Pie Chart Aspek Adoption

\subsubsection{Retention}

Hasil analisis respon responden terhadap aspek Retention menunjukan presentase 34\% untuk jawaban sangat setuju, 24\% untuk jawaban setuju, dan $15 \%$ untuk jawaban netral. Hasil analisis aspek Retention ditunjukkan pada Gambar 7.

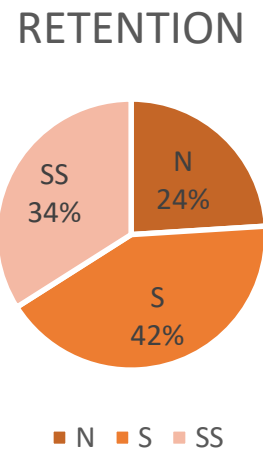

Gambar 7. Pie Chart Aspek Retention 


\subsubsection{Task success}

Hasil analisis respon responden terhadap aspek Task Success menunjukan presentase 38\% untuk jawaban sangat setuju, 50\% untuk jawaban setuju, dan $12 \%$ untuk jawaban netral. Hasil analisis aspek Task Success ditunjukkan pada Gambar 8.

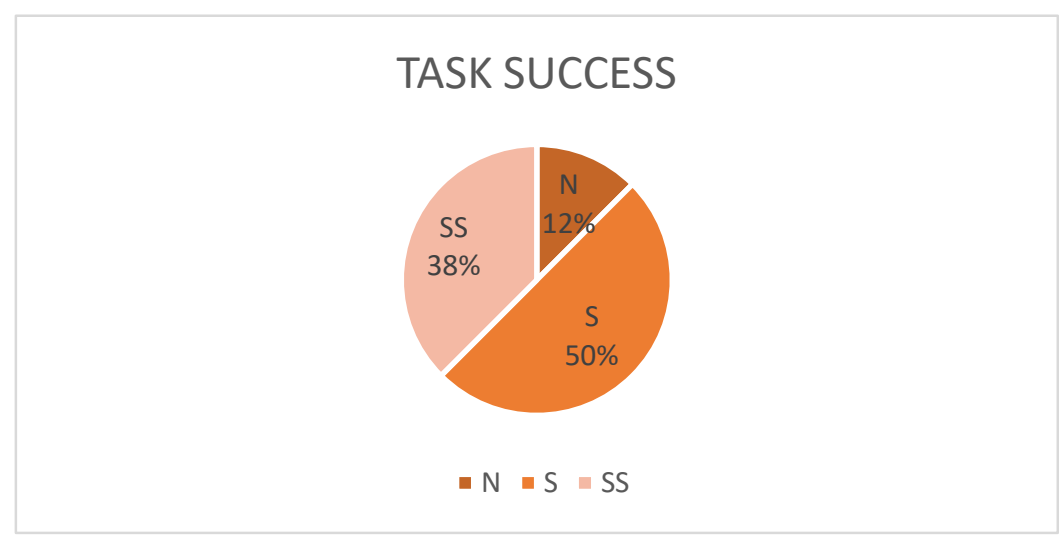

Gambar 8. Pie Chart Aspek Task Success

\section{Kesimpulan}

Sistem informasi rehabilitasi korban penyalahgunaan NAPZA berhasil diimplementasikan kepada pegawai rehabilitasi Kantor BRSKPN Satria. Sistem informasi rehabilitasi tersebut dapat dibangun untuk membantu pegawai rehabilitasi dalam mengelola data rehabilitasi, serta memanajemen proses bisnis rehabilitasi agar lebih terstruktur. Setelah proses implementasi dilaksanakan kemudian dilakukan pengukuran pengalaman pengguna kepada 10 responden pegawai rehabilitasi, dan memperoleh hasil jumlah kriteria Happiness sebesar 0.864, Engagement sebesar 0.8555, Adoption sebesar 0.86, Retention sebesar 0.82, dan Task Success sebesar 0.85. Berdasarkan hasil pengukuran pengalaman pengguna variabel Happiness menjadi skor tertinggi. Hal tersebut menunjukkan bahwa pengguna sangat setuju dalam aspek : kepuasan penggunaan, kemudahan penggunaan, ide tampilan/user interface, kenyamanan penggunaan, dan kebutuhan dalam menggunakan sistem informasi rehabilitasi korban penyalahgunaan NAPZA. Pengukuran pengalaman pengguna atau user experience sistem informasi rehabilitasi menggunakan HEART framework memperoleh hasil Correlation Coefficient pada rentang $0,81<\mathrm{r}<1,00$ yang berarti termasuk pada kriteria "very high". Sistem ini memiliki tingkat reliabilitas sangat baik sehingga sistem dapat dikembangkan dan diterapkan pada Kantor BRSKPN Satria dalam jangka waktu yang lama. Kebaruan dalam penelitian ini adalah penerapan metode HEART framework yang mampu mengukur tingkat usability sebuah sistem informasi.

\section{Referensi}

[1] M. S. Samira Yuliani, T. Prasetyo, and M. Idrus, "Sistem Pakar Pelayanan Dan Penyalahgunaan Narkoba," Infotech J., vol. 4, no. 1, p. 236598, 2018.

[2] BNN, "Kawasan Rawan Narkoba," no. 1, pp. 5-10, 2019.

[3] "BRSKP NAPZA 'SATRIA' DI BATURRADEN." [Online]. Available: https://satria.kemsos.go.id/.

[4] A. Cahyo Nugroho, "Rancang Bangun Sistem Informasi Manajemen Surat Tugas Berbasis Web Menggunakan Waterfall Model," J. Inform. J. Pengemb. IT, vol. 4, no. 2, pp. 146-151, 2019.

[5] V. A. Intanny, I. Widiyastuti, and M. D. K. Perdani, "Pengukuran Kebergunaan dan Pengalaman Pengguna Marketplace Jogjaplaza.id," J. Pekommas, vol. 3, no. 2, p. 117, 2018.

[6] M. L. Khakim and O. O. Sharif, "Analisis User Experience Aplikasi Go-Jek Menggunakan Heart Metrics," e-Proceedings Manag., vol. 5, no. 1, pp. 189-194, 2018.

[7] P. N. Lestari, P. I. Santosa, and R. Ferdiana, "Pengukuran Pengalaman Pengguna Dalam 
Menggunakan Sistem Informasi Akademik," Semin. Nas. Teknol. Inf. dan Komun., vol. 2016, no. Sentika, pp. 2089-9815, 2016.

[8] A. V. Pratama, A. D. Lestari, and Q. Aini, "Analisis User Experience Aplikasi Academic Information System (Ais) Mobile Untuk User-Centered Metrics Menggunakan Heart Framework," Sistemasi, vol. 8, no. 3, p. 405, 2019.

[9] A. Suryadi and Y. S. Zulaikhah, "Rancang Bangun Sistem Pengelolaan Arsip Surat Berbasis Web Menggunakan Metode Waterfall," J. Khatulistiwa Inform., vol. 7, no. 1, pp. 13-21, 2019.

[10] A. F. Zuhri, A. Ahmad, I. Parlina, and R. Dewi, "Sistem Informasi Data Rehabilitasi Narkoba Pada Badan Narkotika Nasional Kota ( BNNK ) Pematangsiantar," pp. 255-260, 2020.

[11] M. Nurdin, A. Muhaemin, T. Informatika, F. Teknik, and U. S. Buana, "Mengukur User Experience Sistem Informasi Akademik," pp. 7-10, 2020.

[12] I. R. Wulandari and L. D. Farida, "Pengukuran User Experience Pada E-Learning Di Lingkungan Universitas Menggunakan User Experience Questionnaire (UEQ)," J. Mantik Penusa, vol. 2, no. 2, pp. 146-151, 2018.

[13] M. Suyanto, "Evaluasi User Experience Pada Sistem Informasi," pp. 1573-1577, 2007.

[14] W. Citra, K. D. Mustika, S. S. Thya, and W. I. Yulita, "E-Boarding KAI access summative usability analysis with adoption of USE questionnaire."

[15] S. T. Safitri, D. M. Kusumawardani, C. Wiguna, D. Supriyadi, and I. Yulita, "Measurement Of Validity And Reliability Of Customer Satisfaction Questioner In E-Boarding Appications," $J$. Pilar Nusa Mandiri, vol. 16, no. 1, pp. 1-6, 2020. 